Neurolmages
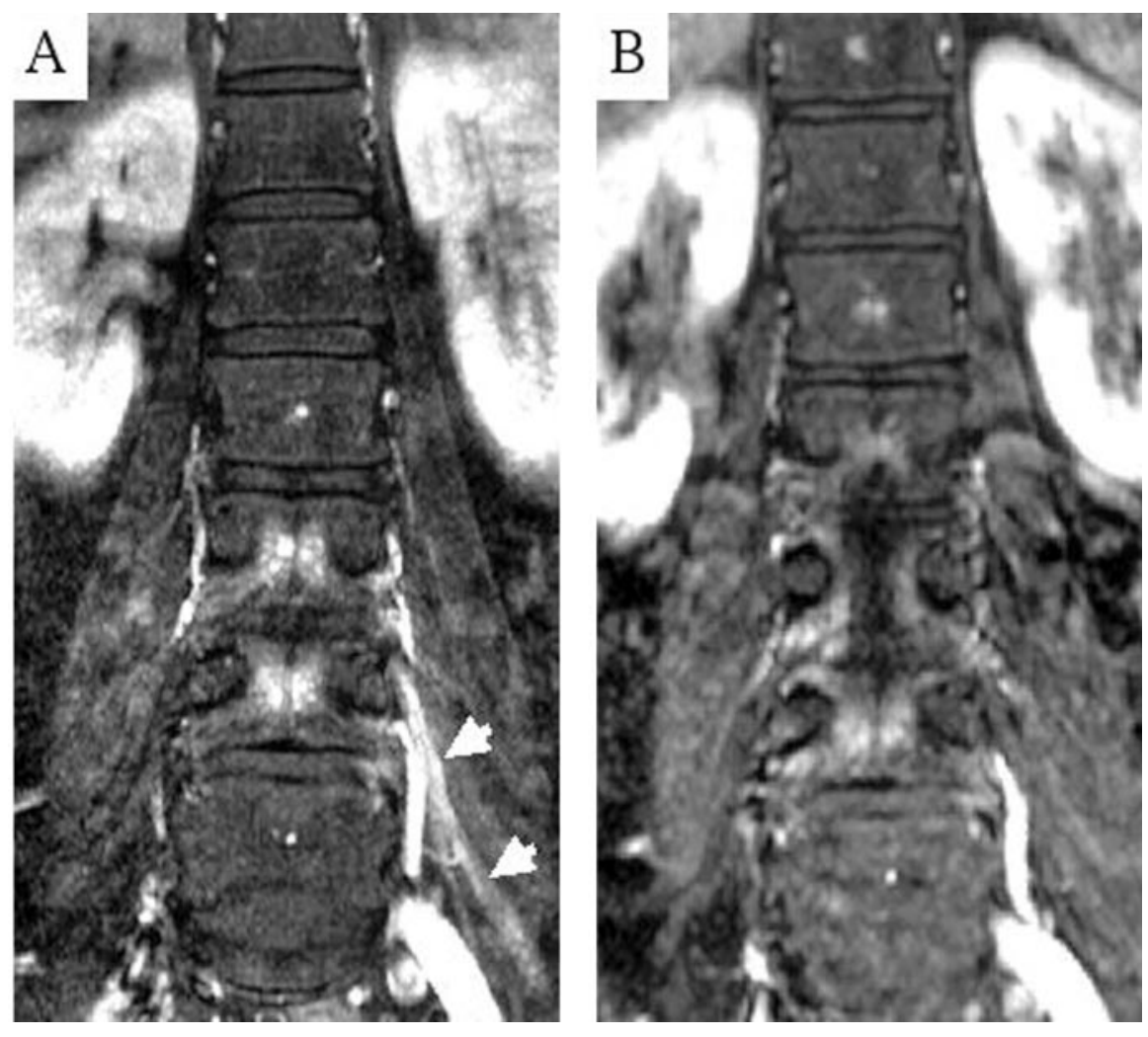

Figure. The coronal view of fat suppression T1 weighted image with gadolinium enhancement shows increased intensities of lumbar plexus mainly located in left L4 (A). Six months after treatment, the enhancement of left lumbar plexus had disappeared (B).

\section{MRI of idiopathic lumbosacral plexopathy}

Kazuhiro Ishii, MD, PhD, Akira Tamaoka, $M D$, PhD, and Shin'ichi Shoji, $M D$, PhD, Tsukuba, Ibaraki, Japan

Idiopathic lumbosacral plexopathy is characterized by an abrupt onset of sensory disturbances, weakness, and loss of deep tendon reflexes of lower extremities, the serial MRI alterations of which have rarely been reported. ${ }^{1}$

Address correspondence and reprint requests to Dr. Kazuhiro Ishii, Department of Neurology, Institute of Clinical Medicine, University of Tsukuba, 1-1-1 Tennoudai, Tsukuba, Ibaraki, 305-8575, Japan; e-mail: kazishii@md.tsukuba.ac.jp
A 43-year-old woman experienced a sudden onset of lumbago, inguinal pain, and dysesthesia in the left L3 and L4 dermatomes with weakness of left iliopsoas and quadriceps muscles. Lumbar MRI revealed abnormalities in the left lumbar plexus (figure). Pulse steroid therapy and IV administration of high-dose immunoglobulin alleviated the symptoms ${ }^{2}$ and the sensorimotor disturbances of her left leg, and abnormalities of lumbar MRI were completely eliminated 6 months later.

1. Yee T. Recurrent idiopathic lumbosacral plexopathy. Muscle Nerve 2000; 23:1439-1442.

2. Triggs WJ, Young MS, Eskin T, Valenstein E. Treatment of idiopathic lumbosacral plexopathy with intravenous immunoglobulin. Muscle Nerve 1997;20:244-246. 


\title{
Neurology
}

\author{
MRI of idiopathic lumbosacral plexopathy \\ Kazuhiro Ishii, Akira Tamaoka and Shin'ichi Shoji \\ Neurology 2004;63;E6 \\ DOI 10.1212/01.WNL.0000134879.61017.DC
}

This information is current as of July 26, 2004

$\begin{array}{ll}\begin{array}{l}\text { Updated Information \& } \\ \text { Services }\end{array} & \begin{array}{l}\text { including high resolution figures, can be found at: } \\ \text { http://n.neurology.org/content/63/2/E6.full }\end{array} \\ \text { Supplementary Material } & \begin{array}{l}\text { Supplementary material can be found at: } \\ \text { http://n.neurology.org/content/suppl/2004/07/07/63.2.E6.DC1 }\end{array} \\ \text { This article cites } 2 \text { articles, } 0 \text { of which you can access for free at: } \\ \text { http://n.neurology.org/content/63/2/E6.full\#ref-list-1 } \\ \text { This article has been cited by } 2 \text { HighWire-hosted articles: } \\ \text { http://n.neurology.org/content/63/2/E6.full\#\#otherarticles } \\ \text { Citations } & \text { This article, along with others on similar topics, appears in the } \\ & \text { following collection(s): } \\ \text { All Neuromuscular Disease } & \text { http://n.neurology.org/cgi/collection/all_neuromuscular_disease } \\ \text { MRI } & \text { http://n.neurology.org/cgi/collection/mri } \\ \text { Peripheral neuropathy } & \text { http://n.neurology.org/cgi/collection/peripheral_neuropathy } \\ & \text { Information about reproducing this article in parts (figures,tables) or in } \\ & \text { its entirety can be found online at: } \\ \text { http://www.neurology.org/about/about_the_journal\#permissions } & \text { Information about ordering reprints can be found online: } \\ \text { Permissions \& Licensing } & \text { http://n.neurology.org/subscribers/advertise }\end{array}$

Neurology ${ }^{\circledR}$ is the official journal of the American Academy of Neurology. Published continuously since 1951, it is now a weekly with 48 issues per year. Copyright . All rights reserved. Print ISSN: 0028-3878. Online ISSN: 1526-632X.

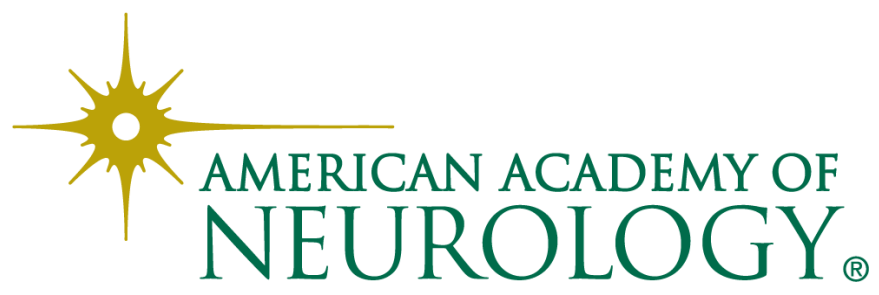

